\title{
Analysis of Ancestral Caddo Ceramic Vessels from Sites in Anderson and Cherokee Counties, Texas
}

Timothy K. Perttula

Follow this and additional works at: https://scholarworks.sfasu.edu/ita

Part of the American Material Culture Commons, Archaeological Anthropology Commons, Environmental Studies Commons, Other American Studies Commons, Other Arts and Humanities Commons, Other History of Art, Architecture, and Archaeology Commons, and the United States History Commons

Tell us how this article helped you.

This Article is brought to you for free and open access by the Center for Regional Heritage Research at SFA ScholarWorks. It has been accepted for inclusion in Index of Texas Archaeology: Open Access Gray Literature from the Lone Star State by an authorized editor of SFA ScholarWorks. For more information, please contact cdsscholarworks@sfasu.edu. 


\section{Analysis of Ancestral Caddo Ceramic Vessels from Sites in Anderson and Cherokee Counties, Texas}

\section{Creative Commons License}

\section{(c) (1) (8)}

This work is licensed under a Creative Commons Attribution-NonCommercial 4.0 International License 


\title{
Analysis of Ancestral Caddo Ceramic Vessels from Sites in Anderson and Cherokee Counties, Texas
}

\author{
Timothy K. Perttula
}

\section{Introduction}

In this article, I document 28 ancestral Caddo ceramic vessels from seven sites and one general collection in the whole vessel collections at the Texas Archeological Research Laboratory (TARL) at The University of Texas at Austin (UT). These sites and general collection are in Anderson and Cherokee counties in East Texas (Figure 1), specifically the: Rube Beard site (41AN18, n=2), the Edward W. Ellis site (41AN36, $n=1$ ), the Ray Lookabaugh site (41AN37, n=1), the R. E. Daly site (41AN39, n=9), the Jasper Tucker/Mrs. Joe Watkins Farm site (41AN44, n=11; see also Perttula and Selden [2015]), the W. T. Todd site (41AN52, n=1), the N. B. Ruggles site (41CE40, n=2), and one vessel from the Cherokee County general collections. The methods of ceramic vessel analysis follow those specified in Perttula (2018:2-4), among other publications on Caddo ceramic vessel documentation, methods consistently employed since the 1990s in the documentation of ancestral Caddo ceramic vessels in East Texas sites.

\section{Natural Regions of Texas}

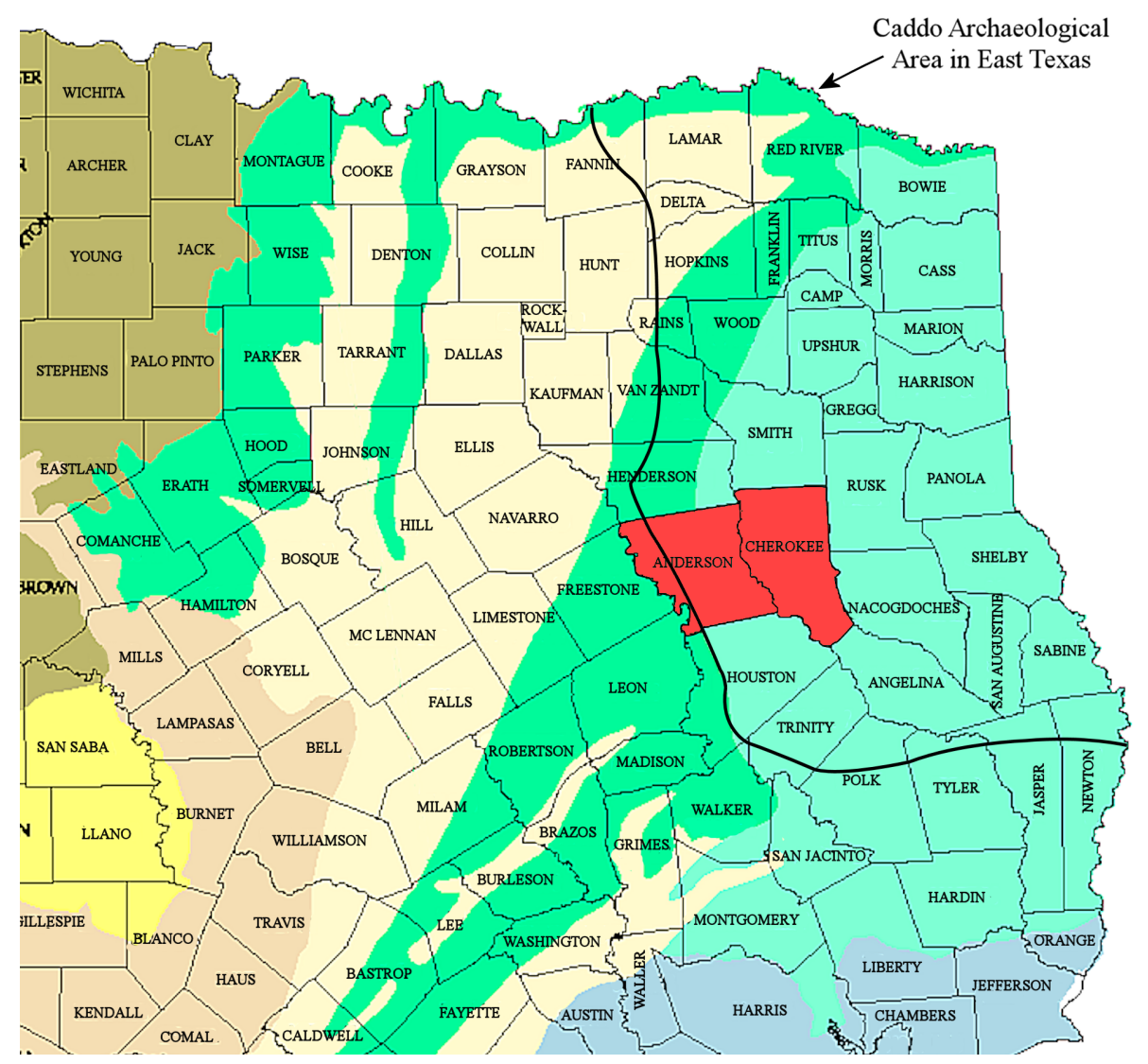

Figure 1. The location of Anderson and Cherokee counties in East Texas. 


\section{Rube Beard Site (41AN18)}

The Rube Beard site is on Brushy Creek, an eastward-flowing tributary to the Neches River, about 2.5 miles south of Frankston, Texas. The two vessels in the TARL collections were exposed by plowing in 1935, and UT purchased them. UT also conducted excavations at the site later in October 1935 (Woolsey 1935a), looking for ancestral Caddo burial features, opening a ca. $14 \times 7 \mathrm{~m}$ area in the vicinity of the one known burial location, but no other burial features were discovered. Woolsey noted that there were two likely contemporaneous Caddo habitation areas within 150-350 yards of the burial, and he collected a small number of ceramic vessel sherds and an elbow pipe sherd with parallel engraved lines on the stem.

SITE NAME OR SITE NUMBER: Rube Beard

VESSEL NO :: AN18-1

VESSEL FORM: Bowl

NON-PLASTICS AND PASTE: grog

RIM AND LIP FORM: Direct rim and rounded lip

CORE COLOR: F (fired in a reducing environment and cooled in the open air)

INTERIOR SURFACE COLOR: reddish-brown

EXTERIOR SURFACE COLOR: reddish-brown; fire clouds on the body and base

WALL THICKNESS (IN MM): rim, $7.0 \mathrm{~mm}$; body, $8.2 \mathrm{~mm}$

INTERIOR SURFACE TREATMENT: smoothed

EXTERIOR SURFACE TREATMENT: burnished

HEIGHT (IN CM): 10.8

ORIFICE DIAMETER (IN CM): 19.7

DIAMETER AT BOTTOM OF RIM OR NECK (IN CM): N/A

BASE DIAMETER (IN CM) AND SHAPE OF BASE: $11.7 \mathrm{~cm}$, circular and flat

ESTIMATED VOLUME (IN LITERS): 0.9

DECORATION (INCLUDING MOTIF AND ELEMENTS WHEN APPARENT): The rim of the vessel has three horizontal engraved lines (Figure 2).

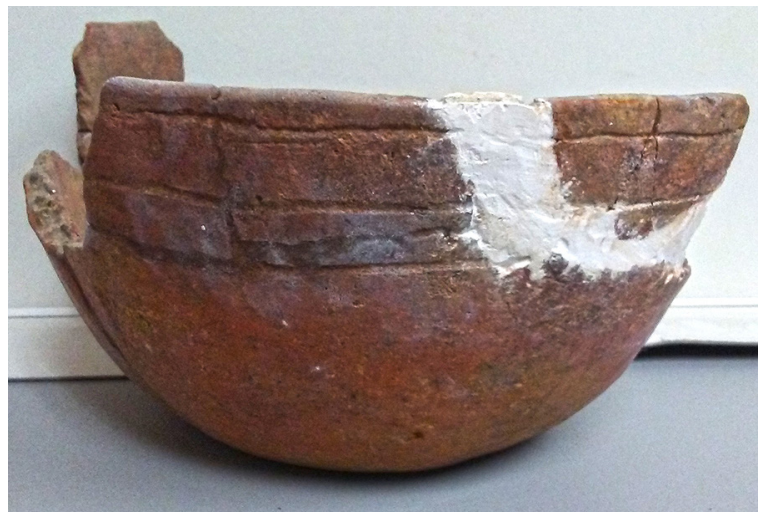

Figure 2. cf. Hood Engraved, var. Hood bowl (AN181) from the Rube Beard site.

\section{PIGMENT USE AND LOCATION ON VESSEL: none}

TYPE AND VARIETY (IF KNOWN): cf. Hood Engraved, var. Hood. Although this vessel does not have an effigy head, the three horizontal engraved lines on the rim are stylistically consistent with Hood Engraved, var. Hood (Perttula 2011:271). 
SITE NAME OR SITE NUMBER: Rube Beard

VESSEL NO.: AN18-2

VESSEL FORM: Bowl

NON-PLASTICS AND PASTE: grog

RIM AND LIP FORM: N/A

CORE COLOR: $\mathrm{F}$ (fired in a reducing environment and cooled in the open air)

INTERIOR SURFACE COLOR: reddish-brown; fire clouds on the body and base

EXTERIOR SURFACE COLOR: reddish-brown; fire clouds on the body and base

WALL THICKNESS (IN MM): body, $6.5 \mathrm{~mm}$; base, $8.9 \mathrm{~mm}$

INTERIOR SURFACE TREATMENT: none

EXTERIOR SURFACE TREATMENT: smoothed

HEIGHT (IN CM): 5.7+

ORIFICE DIAMETER (IN CM): N/A

DIAMETER AT BOTTOM OF RIM OR NECK (IN CM): 9.4

BASE DIAMETER (IN CM) AND SHAPE OF BASE: $6.7 \mathrm{~cm}$, circular and flat

ESTIMATED VOLUME (IN LITERS): $0.2+$

DECORATION (INCLUDING MOTIF AND

ELEMENTS WHEN APPARENT): The vessel body has portions of an engraved hooked arm element inside of an engraved oval (Figure 3).

PIGMENT USE AND LOCATION ON VESSEL: none

TYPE AND VARIETY (IF KNOWN): Poynor

Engraved, var. $N$ (see Perttula 2011:Figure 6-65)

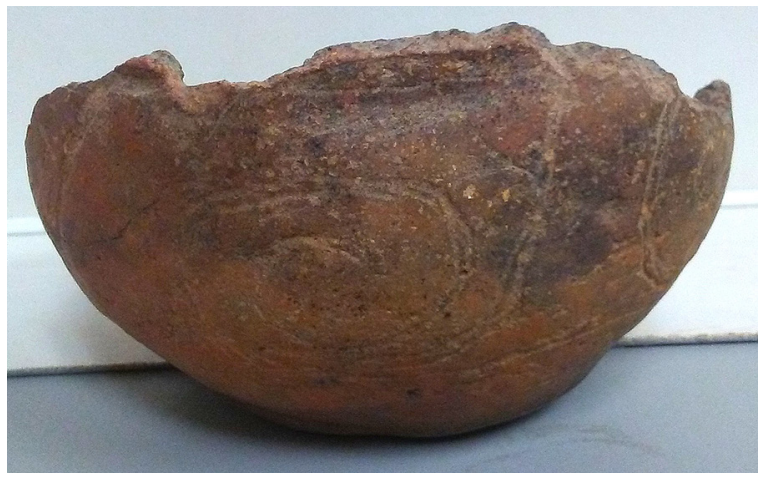

Figure 3. Poynor Engraved, var. $N$ bowl (AN18-2) from the Rube Beard site. 


\section{Edward W. Ellis Site (41AN36)}

The Edward W. Ellis site is in an agricultural field adjacent to Boggy Creek, a tributary of the Neches River; it is 6 miles south of Frankston, Texas. The landowner had found a burial with preserved skeletal remains in 1930 at the site along with four ceramic vessels and a ceramic pipe. One of the vessels was obtained by UT, who also conducted trench excavations at the site to look for other ancestral Caddo burial features (Jackson 1931). These excavations did not locate any additional burial features, but did recover ceramic sherds and a ceramic pipe from likely habitation contexts. The ceramic sherds from these deposits are primarily from Poynor Engraved $(n=8)$ and Bullard Brushed $(n=38)$ vessels, and there was one Hood Engraved effigy vessel appendage. The ceramic elbow pipe sherd from the site has engraved concentric circles on the lower part of the stem, while the area beneath the stem lip has four horizontal incised lines. A virtually similar ceramic elbow pipe has been documented at the A. C. Saunders site (41AN19).

SITE NAME OR SITE NUMBER: Edward W. Ellis

VESSEL NO.: AN36-18; donated by W. D. Powell

VESSEL FORM: Carinated bowl (body and base only)

NON-PLASTICS AND PASTE: grog and hematite

RIM AND LIP FORM: N/A

CORE COLOR: F (fired in a reducing environment and cooled in the open air)

INTERIOR SURFACE COLOR: reddish-brown; fire clouds on the body and base; organic residue on the body

EXTERIOR SURFACE COLOR: reddish-brown; fire clouds on the body and base; organic residue on the body

WALL THICKNESS (IN MM): body, $8.4 \mathrm{~mm}$

INTERIOR SURFACE TREATMENT: smoothed

EXTERIOR SURFACE TREATMENT: burnished

HEIGHT (IN CM): $8.5+$

ORIFICE DIAMETER (IN CM): N/A

DIAMETER AT BOTTOM OF RIM OR NECK (IN CM): 21.1

BASE DIAMETER (IN CM) AND SHAPE OF BASE: $7.5 \mathrm{~cm}$, circular and flat

ESTIMATED VOLUME (IN LITERS): 1.1+

DECORATION (INCLUDING MOTIF AND ELEMENTS WHEN APPARENT): There is a single horizontal engraved line visible on the remnants of the rim panel. The remainder of the rim panel is missing. 
PIGMENT USE AND LOCATION ON VESSEL: none

TYPE AND VARIETY (IF KNOWN): Unidentified fine ware

\section{Ray Lookabaugh Site (41AN37)}

The Ray Lookabaugh site is near Boggy Creek, an eastward-flowing tributary of the Neches River, in the upper Neches River basin, seven miles southeast of Frankston, Texas. A vessel was plowed up in 1928 at the site, and subsequently donated by the landowner to UT in 1931 .

SITE NAME OR SITE NUMBER: Ray Lookabaugh

VESSEL NO.: AN37-1; Donated to UT in 1931

VESSEL FORM: Jar with opposed lug handles (27 x $11 \mathrm{~mm}$ in length and width) (Figure 4)

NON-PLASTICS AND PASTE: grog

RIM AND LIP FORM: Direct rim and rounded lip

CORE COLOR: $\mathrm{F}$ (fired in a reducing environment and cooled in the open air)

INTERIOR SURFACE COLOR: yellowish-brown; organic residue on the rim and body

EXTERIOR SURFACE COLOR: yellowish-brown; fire clouds on the rim, body, and base; organic residue on the rim and body

WALL THICKNESS (IN MM): rim, $5.0 \mathrm{~mm}$

INTERIOR SURFACE TREATMENT: smoothed

EXTERIOR SURFACE TREATMENT: smoothed on the body

HEIGHT (IN CM): 9.6

ORIFICE DIAMETER (IN CM): 10.5

DIAMETER AT BOTTOM OF RIM OR NECK (IN CM): 10.3

BASE DIAMETER (IN CM) AND SHAPE OF BASE: $8.3 \mathrm{~cm}$, circular and flat

ESTIMATED VOLUME (IN LITERS): 0.6

DECORATION (INCLUDING MOTIF AND ELEMENTS WHEN APPARENT): The rim has seven sets of diagonal opposed incised triangle elements filled with tool punctations (Figure 4).

PIGMENT USE AND LOCATION ON VESSEL: none

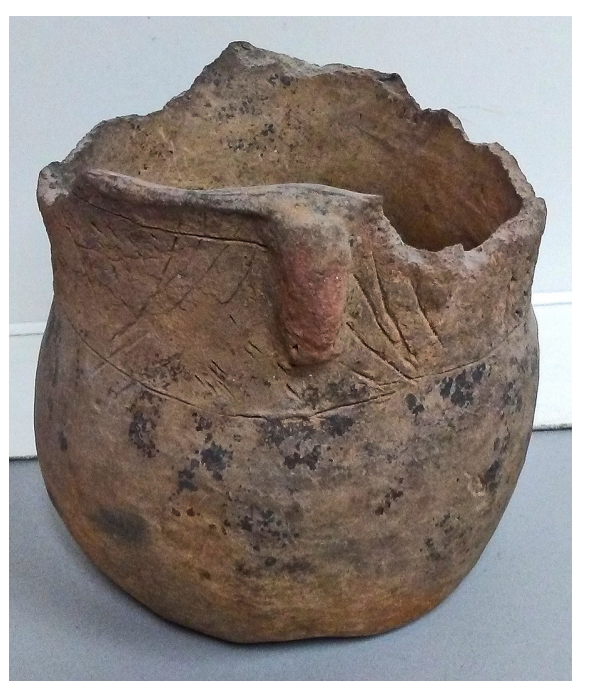

Figure 4. Maydelle Incised jar (AN371) from the Ray Lookabaugh site.

TYPE AND VARIETY (IF KNOWN): Maydelle Incised 


\section{R. E. Daly Site (41AN39)}

The R. E. Daly site, 3 miles north of Neches, Texas, in the upper Neches River basin, was found by the landowner a number of years before 1926, when at least one grave was washed out by flooding along Garrett Creek. UT purchased the vessels in August 1926.

SITE NAME OR SITE NUMBER: R. E. Daly

VESSEL NO.: AN39-4

VESSEL FORM: Jar with four pedestal legs (32 x $21 \mathrm{~mm}$ in height and width) and two strap handles (39 x $25 \mathrm{~mm}$ in length and width) (Figure 5)

NON-PLASTICS AND PASTE: grog

RIM AND LIP FORM: Direct rim and rounded lip

CORE COLOR: $\mathrm{F}$ (fired in a reducing environment and cooled in the open air)

INTERIOR SURFACE COLOR: reddish-brown

EXTERIOR SURFACE COLOR: reddish-brown; fire clouds on the pedestal base

WALL THICKNESS (IN MM): rim, $5.5 \mathrm{~mm}$

INTERIOR SURFACE TREATMENT: smoothed

EXTERIOR SURFACE TREATMENT: none

HEIGHT (IN CM): 12.2

ORIFICE DIAMETER (IN CM): 10.6

DIAMETER AT BOTTOM OF RIM OR NECK (IN CM): 10.3

BASE DIAMETER (IN CM) AND SHAPE OF BASE: $8.9 \mathrm{~cm}$, circular and flat

ESTIMATED VOLUME (IN LITERS): 0.6

DECORATION (INCLUDING MOTIF AND ELEMENTS WHEN

APPARENT): The vessel rim has seven sets of vertical pinched panels, and the two strap handles have vertical pinched rows (Figure 5). The vessel body has four sets of concentric pinched circles divided by vertical pinched rows. The pedestal legs also have vertical pinched rows.

PIGMENT USE AND LOCATION ON VESSEL: none

TYPE AND VARIETY (IF KNOWN): Killough Pinched

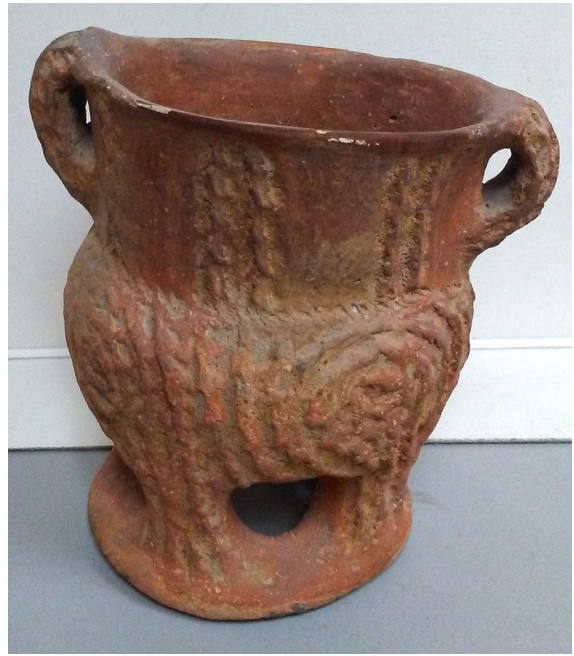

Figure 5. Killough Pinched pedestal base jar (AN39-4) from the R. E. Daly site. 
SITE NAME OR SITE NUMBER: R. E. Daly

VESSEL NO.: AN39-5

VESSEL FORM: Carinated bowl

NON-PLASTICS AND PASTE: grog

RIM AND LIP FORM: Direct rim and rounded lip

CORE COLOR: $\mathrm{F}$ (fired in a reducing environment and cooled in the open air)

INTERIOR SURFACE COLOR: light reddish-brown; fire clouds on the base

EXTERIOR SURFACE COLOR: light reddish-brown; fire clouds on the rim, body, and base

WALL THICKNESS (IN MM): rim, $5.4 \mathrm{~mm}$

INTERIOR SURFACE TREATMENT: smoothed

EXTERIOR SURFACE TREATMENT: burnished

HEIGHT (IN CM): 3.7

ORIFICE DIAMETER (IN CM): 7.7

DIAMETER AT BOTTOM OF RIM OR NECK (IN CM): 7.7

BASE DIAMETER (IN CM) AND SHAPE OF BASE: $4.3 \mathrm{~cm}$, circular and flat

ESTIMATED VOLUME (IN LITERS): 0.2

DECORATION (INCLUDING MOTIF AND

ELEMENTS WHEN APPARENT): Plain (Figure 6)

PIGMENT USE AND LOCATION ON VESSEL: none

TYPE AND VARIETY (IF KNOWN): Unidentified plain ware

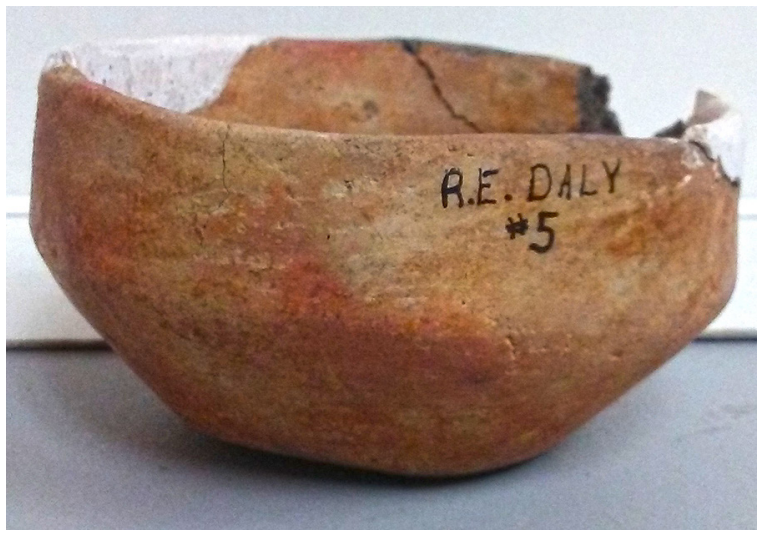

Figure 6. Plain carinated bowl (AN39-5) from the R. E. Daly site. 
SITE NAME OR SITE NUMBER: R. E. Daly

VESSEL NO.: AN39-6

VESSEL FORM: Bottle with a collar (4.0 mm in width) at the base of the neck (Figure 7)

NON-PLASTICS AND PASTE: grog

RIM AND LIP FORM: Direct rim and rounded lip

CORE COLOR: $\mathrm{G}$ (fired in a reducing environment and cooled in the open air)

INTERIOR SURFACE COLOR: dark gray

EXTERIOR SURFACE COLOR: yellowish-brown; fire clouds on the rim, body, and base

WALL THICKNESS (IN MM): rim, $5.6 \mathrm{~mm}$

INTERIOR SURFACE TREATMENT: none

EXTERIOR SURFACE TREATMENT: smoothed

HEIGHT (IN CM): 20.4

ORIFICE DIAMETER (IN CM): 5.7

DIAMETER AT BOTTOM OF RIM OR NECK (IN CM): $6.5 \mathrm{~cm}$; maximum body diameter: $13.3 \mathrm{~cm}$

BASE DIAMETER (IN CM) AND SHAPE OF BASE: $7.6 \mathrm{~cm}$, circular and flat

ESTIMATED VOLUME (IN LITERS): 0.6

DECORATION (INCLUDING MOTIF AND ELEMENTS WHEN

APPARENT): The vessel body is divided into three panels by sets of three vertical engraved lines. Within the panels are sets of two semicircular engraved lines, and the outer semi-circular line has a series of hatched pendant triangle elements (Figure 7). The corners of the panels have curvilinear hatched triangle elements.

PIGMENT USE AND LOCATION ON VESSEL: red pigment in the engraved lines

TYPE AND VARIETY (IF KNOWN): Poynor Engraved, var. unspecified (see Suhm and Jelks 1962:Plate 63g)

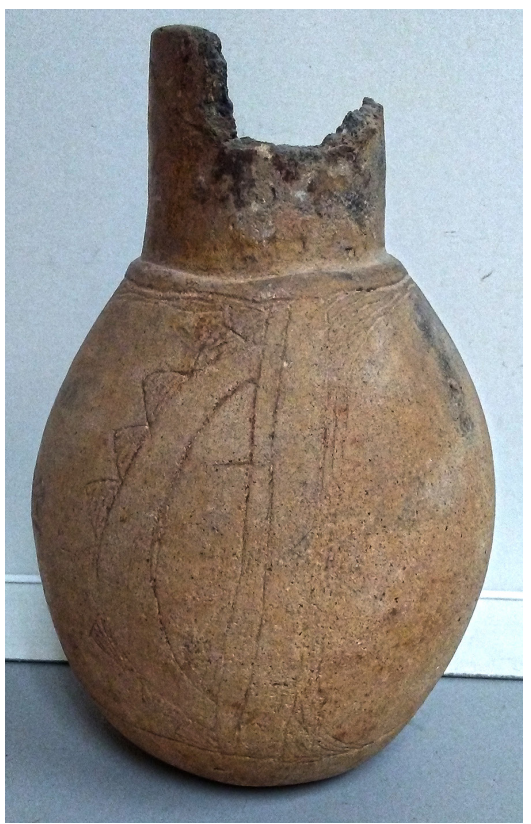

Figure 7. Poynor Engraved, var. unspecified bottle (AN39-6) from the R. E. Daly site. 
SITE NAME OR SITE NUMBER: R. E. Daly

VESSEL NO.: AN39-7

VESSEL FORM: Bottle

NON-PLASTICS AND PASTE: grog and hematite

RIM AND LIP FORM: Direct rim and rounded lip

CORE COLOR: $\mathrm{F}$ (fired in a reducing environment and cooled in the open air)

INTERIOR SURFACE COLOR: brown

EXTERIOR SURFACE COLOR: brown; fire clouds on the body and base

WALL THICKNESS (IN MM): neck, $4.3 \mathrm{~mm}$

INTERIOR SURFACE TREATMENT: none

EXTERIOR SURFACE TREATMENT: smoothed

HEIGHT (IN CM): 15.8

ORIFICE DIAMETER (IN CM): 3.8

DIAMETER AT BOTTOM OF RIM OR NECK (IN CM): $4.9 \mathrm{~cm}$, maximum body diameter: $11.9 \mathrm{~cm}$ BASE DIAMETER (IN CM) AND SHAPE OF BASE: $5.3 \mathrm{~cm}$, circular and flat

ESTIMATED VOLUME (IN LITERS): 0.4

\section{DECORATION (INCLUDING MOTIF AND ELEMENTS}

WHEN APPARENT): The vessel body is divided into three panels by sets of closely-spaced curvilinear engraved lines with upper and lower hatched or excised triangle elements (Figure 8). Two of the panels have large pendant triangles with horizontal or diagonal hatched corners.

PIGMENT USE AND LOCATION ON VESSEL: none

TYPE AND VARIETY (IF KNOWN): Poynor Engraved, var. unspecified

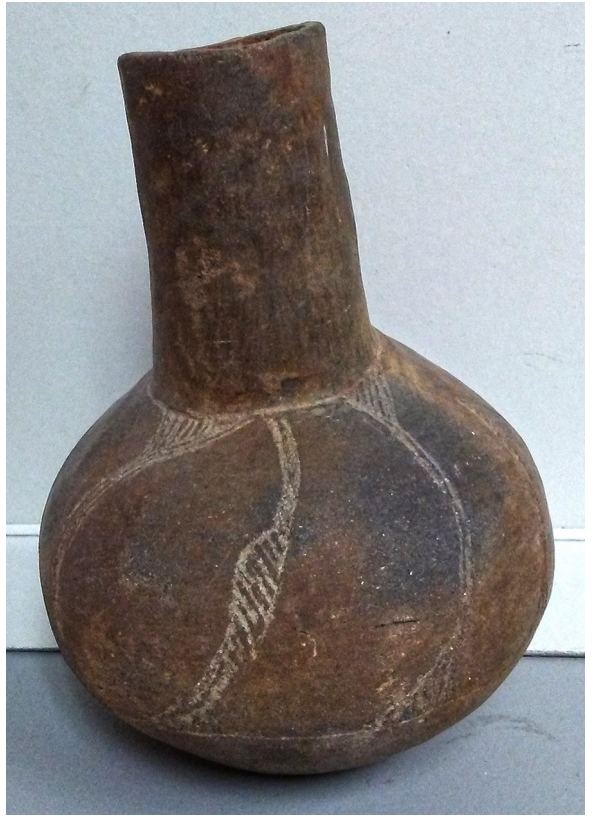

Figure 8. Poynor Engraved, var. unspecified bottle (AN39-7) from the R. E. Daly site. 
SITE NAME OR SITE NUMBER: R. E. Daly

VESSEL NO.: AN39-9

VESSEL FORM: Globular carinated bowl

NON-PLASTICS AND PASTE: grog

RIM AND LIP FORM: Direct rim and rounded, exterior folded, lip

CORE COLOR: $\mathrm{F}$ (fired in a reducing environment and cooled in the open air)

INTERIOR SURFACE COLOR: dark reddish-brown

EXTERIOR SURFACE COLOR: dark reddish-brown; fire clouds on the rim, body, and base

WALL THICKNESS (IN MM): rim, $4.6 \mathrm{~mm}$

INTERIOR SURFACE TREATMENT: smoothed

EXTERIOR SURFACE TREATMENT: burnished

HEIGHT (IN CM): 11.0

ORIFICE DIAMETER (IN CM): 13.5

DIAMETER AT BOTTOM OF RIM OR NECK (IN CM): 13.6

BASE DIAMETER (IN CM) AND SHAPE OF BASE: $6.4 \mathrm{~cm}$, circular and flat

ESTIMATED VOLUME (IN LITERS): 0.9

DECORATION (INCLUDING MOTIF AND ELEMENTS

WHEN APPARENT): The rim panel has six widely-spaced sets of engraved bracket elements filled with excised punctations (Figure 9).

PIGMENT USE AND LOCATION ON VESSEL: none

TYPE AND VARIETY (IF KNOWN): Poynor Engraved, var. Hood (Perttula 2011:Figure 6-64e)

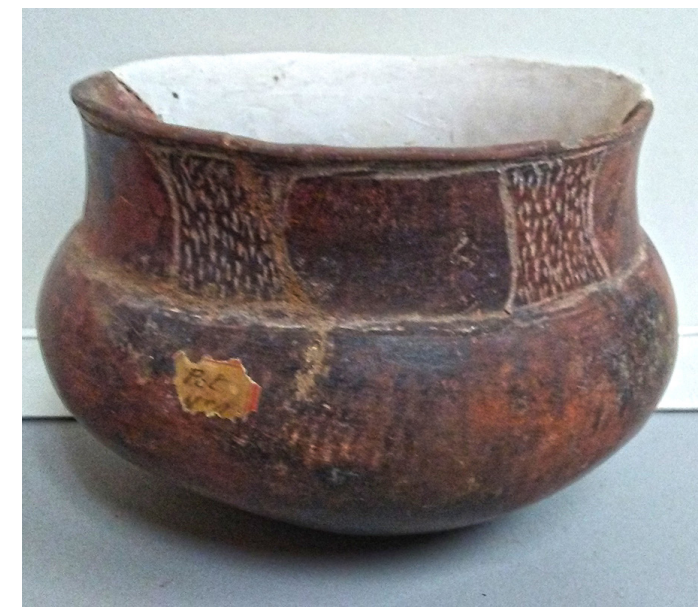

Figure 9. Poynor Engraved, var. Hood carinated bowl (AN39-9) from the R. E. Daly site. 
SITE NAME OR SITE NUMBER: R. E. Daly

VESSEL NO.: AN39-10

VESSEL FORM: Jar with two strap handles (33 x $19 \mathrm{~mm}$ in length and width) (Figure 10)

NON-PLASTICS AND PASTE: grog and hematite

RIM AND LIP FORM: Direct rim and rounded lip

CORE COLOR: G (fired in a reducing environment and cooled in the open air)

INTERIOR SURFACE COLOR: very dark grayish-brown

EXTERIOR SURFACE COLOR: reddish-brown; fire clouds on the rim, body, and base

WALL THICKNESS (IN MM): rim, $6.5 \mathrm{~mm}$

INTERIOR SURFACE TREATMENT: smoothed

EXTERIOR SURFACE TREATMENT: none

HEIGHT (IN CM): 14.0

ORIFICE DIAMETER (IN CM): 11.2

DIAMETER AT BOTTOM OF RIM OR NECK (IN CM): 11.3

BASE DIAMETER (IN CM) AND SHAPE OF BASE: $7.3 \mathrm{~cm}$, circular and flat

ESTIMATED VOLUME (IN LITERS): 0.9

DECORATION (INCLUDING MOTIF AND ELEMENTS WHEN APPARENT): The vessel rim has diagonal incised lines, while the vessel body has vertical brushing marks to within $3.4 \mathrm{~cm}$ of the base (Figure 10). The strap handles have vertical pinched ridges.

PIGMENT USE AND LOCATION ON VESSEL: none TYPE AND VARIETY (IF KNOWN): Maydelle Incised

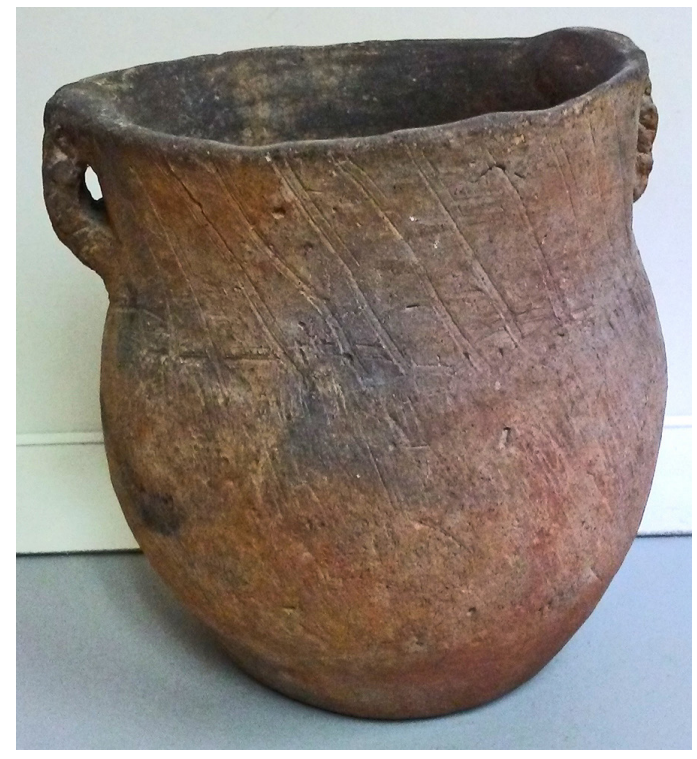

Figure 10. Maydelle Incised jar (AN39-10) from the R. E. Daly site. 
SITE NAME OR SITE NUMBER: R. E. Daly

VESSEL NO.: AN39-11

VESSEL FORM: Carinated bowl

NON-PLASTICS AND PASTE: grog

RIM AND LIP FORM: Inverted rim with a rounded and scalloped lip (Figure 11)

CORE COLOR: $\mathrm{F}$ (fired in a reducing environment and cooled in the open air)

INTERIOR SURFACE COLOR: brown; fire clouds on the base

EXTERIOR SURFACE COLOR: brown; fire clouds on the body and base

WALL THICKNESS (IN MM): rim, $6.4 \mathrm{~mm}$

INTERIOR SURFACE TREATMENT: burnished

EXTERIOR SURFACE TREATMENT: burnished

HEIGHT (IN CM): 10.8

ORIFICE DIAMETER (IN CM): 16.1

DIAMETER AT BOTTOM OF RIM OR NECK (IN CM): 16.4

BASE DIAMETER (IN CM) AND SHAPE OF BASE: $8.3 \mathrm{~cm}$, circular and flat

ESTIMATED VOLUME (IN LITERS): 1.0

DECORATION (INCLUDING MOTIF AND ELEMENTS WHEN APPARENT): The rim panel has 10 sets of curvilinear and hatched engraved bracket elements, forming negative circles and ovals (Figure 11).

PIGMENT USE AND LOCATION ON VESSEL: none

TYPE AND VARIETY (IF KNOWN): Poynor Engraved, var. Cook

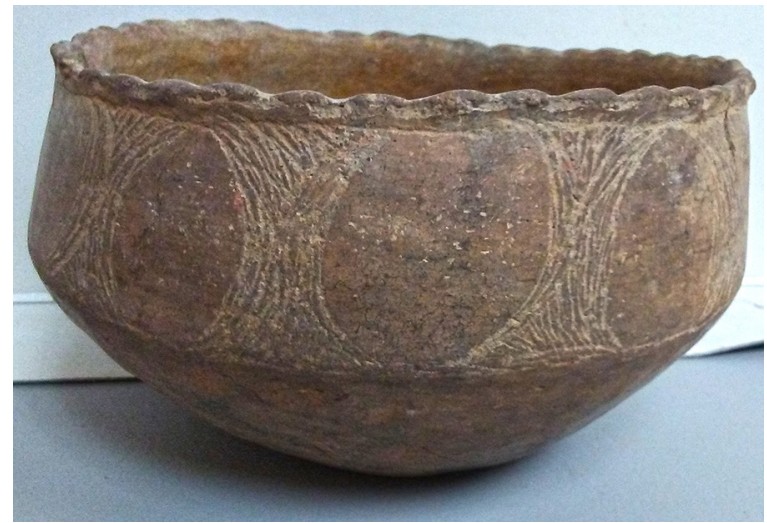

Figure 11. Poynor Engraved, var. Cook carinated bowl (AN39-11) from the R. E. Daly site. 
SITE NAME OR SITE NUMBER: R. E. Daly

VESSEL NO.: AN39-12

VESSEL FORM: Carinated bowl

NON-PLASTICS AND PASTE: grog

RIM AND LIP FORM: Inverted rim and flat lip

CORE COLOR: $\mathrm{F}$ (fired in a reducing environment and cooled in the open air)

INTERIOR SURFACE COLOR: brown

EXTERIOR SURFACE COLOR: brown; fire clouds on the body and base

WALL THICKNESS (IN MM): rim, $7.9 \mathrm{~mm}$

INTERIOR SURFACE TREATMENT: smoothed

EXTERIOR SURFACE TREATMENT: smoothed

HEIGHT (IN CM): 9.8

ORIFICE DIAMETER (IN CM): 13.2

DIAMETER AT BOTTOM OF RIM OR NECK (IN CM): 15.6

BASE DIAMETER (IN CM) AND SHAPE OF BASE: $7.6 \mathrm{~cm}$, circular and flat

ESTIMATED VOLUME (IN LITERS): 0.8

DECORATION (INCLUDING MOTIF AND

ELEMENTS WHEN APPARENT): The rim panel has 11 negative ovals and circles defined by sets of closely-spaced curvilinear engraved lines (Figure 12). There are upper and lower diagonal hatched triangle elements attached to the sets of curvilinear engraved lines.

PIGMENT USE AND LOCATION ON VESSEL: none

TYPE AND VARIETY (IF KNOWN):

Poynor Engraved, var. Cook

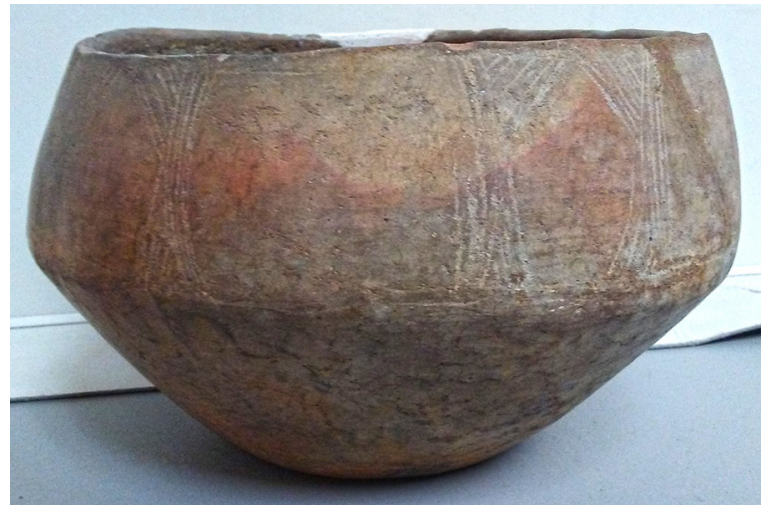

Figure 12. Poynor Engraved, var. Cook carinated bowl (AN39-12) from the R. E. Daly site. 
SITE NAME OR SITE NUMBER: R. E. Daly

VESSEL NO.: AN39-13

VESSEL FORM: Rectangular bowl (Figure 13a-b)

NON-PLASTICS AND PASTE: grog

RIM AND LIP FORM: Direct rim and flat lip, with four widened ends or corners (Figure 13b)

CORE COLOR: $\mathrm{F}$ (fired in a reducing environment and cooled in the open air)

INTERIOR SURFACE COLOR: brown

EXTERIOR SURFACE COLOR: brown

WALL THICKNESS (IN MM): rim, $6.5 \mathrm{~mm}$

INTERIOR SURFACE TREATMENT: smoothed

EXTERIOR SURFACE TREATMENT: burnished

HEIGHT (IN CM): 5.5

ORIFICE DIAMETER (IN CM): $9.2 \times 5.6 \mathrm{~cm}$

DIAMETER AT BOTTOM OF RIM OR NECK (IN CM): N/A

BASE DIAMETER (IN CM) AND SHAPE OF BASE: $7.3 \times 4.8 \mathrm{~cm}$

ESTIMATED VOLUME (IN LITERS): 0.1

DECORATION (INCLUDING MOTIF AND ELEMENTS WHEN APPARENT): The vessel has three widely-spaced horizontal engraved lines (Figure 13a).

\section{PIGMENT USE AND LOCATION ON VESSEL:} none

TYPE AND VARIETY (IF KNOWN): cf. Hood Engraved, var. Hood
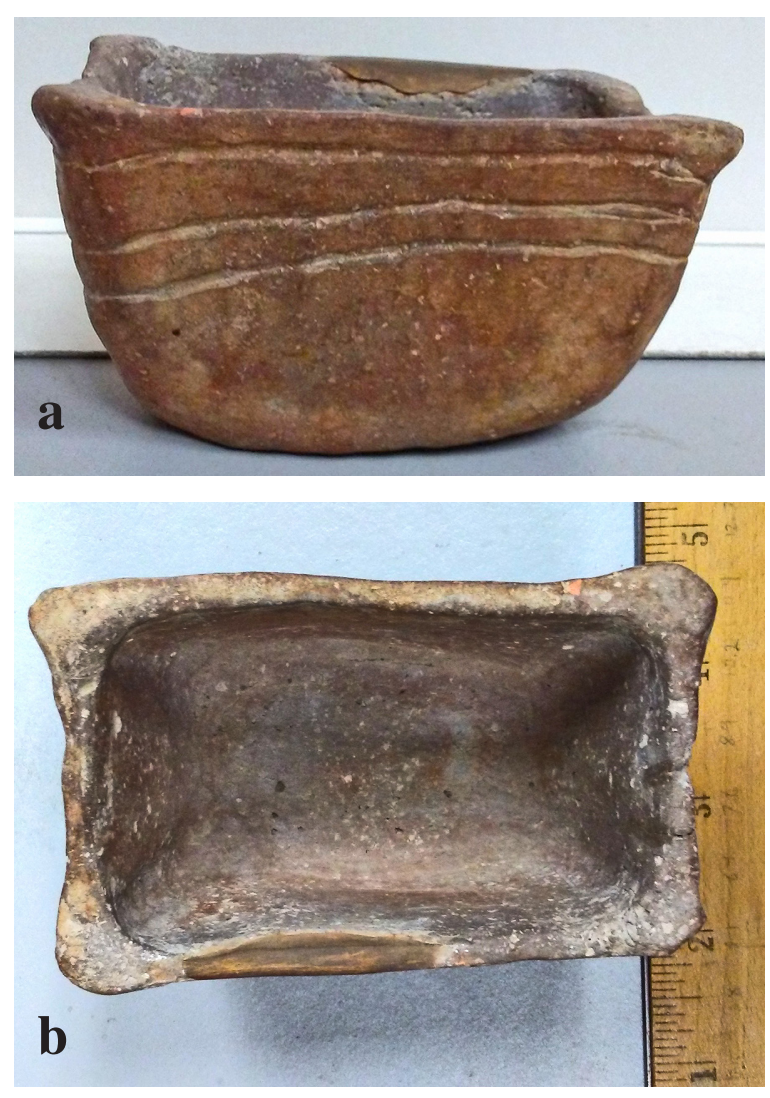

Figure 13. cf. Hood Engraved, var. Hood rectangular bowl (AN39-13) from the R. E. Daly site: a, side view; b, top-down view. 


\section{Jasper Tucker/Mrs. Joe Watkins Farm Site (41AN44)}

The Jasper Tucker/Mrs. Joe Watkins Farm site is a Late Caddo period Frankston phase habitation site and small cemetery in the upper Neches River basin in East Texas. There are three known burials from the site, one dug by local farmers and the other two excavated by UT archaeologists in November 1935 (Woolsey 1935b). The two burials excavated by UT had 11 ceramic vessels (including Poynor Engraved and Maydelle Incised vessels), an L-shaped elbow pipe, and five Perdiz arrow points as funerary offerings. One burial (AO-1) had five effigy bowls, and burial AO-2 had one effigy bowl. The proportion of effigy bowls among the vessels (55 percent) in the two burials is particularly notable.

SITE NO.: 41AN44

FEATURE: Burial AO-1

VESSEL NO.: AN44-3

NON-PLASTICS: grog

VESSEL FORM: Bowl

RIM AND LIP FORM: direct rim and rounded lip

CORE COLOR: $\mathrm{F}$ (fired in a reducing environment but cooled in the open air)

INTERIOR SURFACE COLOR: reddish-brown

EXTERIOR SURFACE COLOR: reddish-brown; fire clouds on the body and base

WALL THICKNESS: rim, $6.2 \mathrm{~mm}$

INTERIOR SURFACE TREATMENT: smoothed

EXTERIOR SURFACE TREATMENT: smoothed

HEIGHT: 10.5

ORIFICE DIAMETER: 16.9

DIAMETER AT BOTTOM OF RIM OR NECK: N/A

BASE DIAMETER AND SHAPE: 11.2; circular and flat

ESTIMATED VOLUME: 0.7 liters

DECORATION: three horizontal engraved lines around the rim; the engraved lines dip under the effigy head and tab tail. The effigy head on this vessel has been broken off (Figure 14). The tab tail is $55 \times 21 \times 8 \mathrm{~mm}$ in width, length, and thickness.

PIGMENT: none

TYPE: Hood Engraved, var. Hood

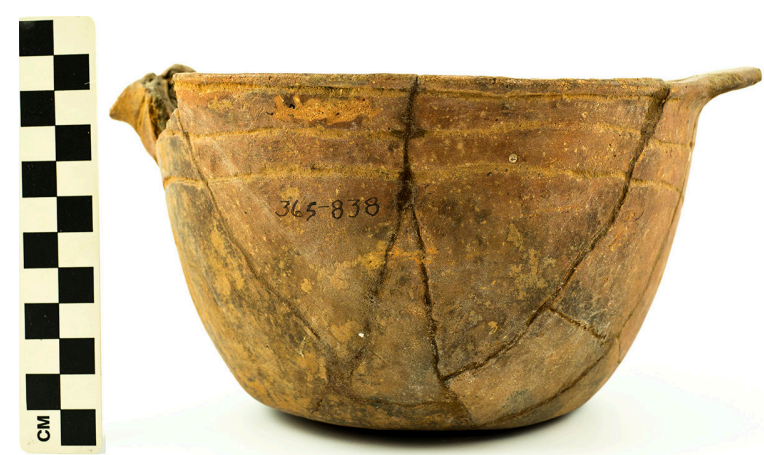

Figure 14. Hood Engraved, var. Hood effigy bowl (AN44-3) from the Jasper Tucker/Mrs. Joe Watkins Farm site. 
SITE NO.: 41AN44

FEATURE: Burial AO-1

VESSEL NO.: AN44-4

NON-PLASTICS: grog and hematite

VESSEL FORM: Bowl

RIM AND LIP FORM: direct rim and rounded lip

CORE COLOR: A (fired and cooled in an oxidizing environment)

INTERIOR SURFACE COLOR: light brown; fire clouds on the rim

EXTERIOR SURFACE COLOR: brown; fire clouds on the rim and body

WALL THICKNESS: rim, $5.7 \mathrm{~mm}$

INTERIOR SURFACE TREATMENT: smoothed

EXTERIOR SURFACE TREATMENT: smoothed

HEIGHT: 8.0

ORIFICE DIAMETER: 15.1

DIAMETER AT BOTTOM OF RIM OR NECK: N/A

BASE DIAMETER AND SHAPE: 9.5; circular and flat

ESTIMATED VOLUME: 0.48 liters

DECORATION: four horizontal lines on the vessel rim; the engraved lines do not dip under the effigy head or tab tail. The effigy head is broken off, but the tab tail is $42 \times 24 \times 8 \mathrm{~mm}$ in length, width, and thickness (Figure 15).

PIGMENT: none

TYPE: Hood Engraved, var. Hood

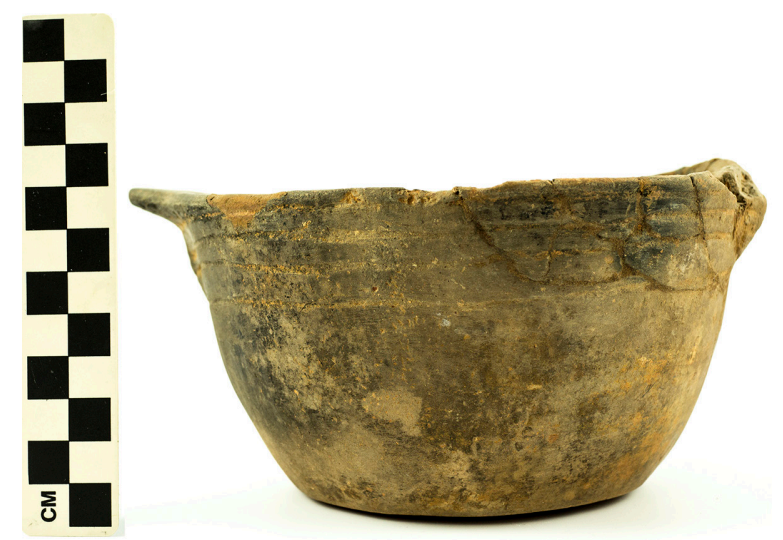

Figure 15. Hood Engraved, var. Hood effigy bowl (AN44-4) from the Jasper Tucker/Mrs. Joe Watkins Farm site. 
SITE NAME OR SITE NUMBER: 41AN44

VESSEL NO.: AN44-5, Burial AO-1

VESSEL FORM: Jar with two rim peaks and perforated lug handles (43 x $18 \mathrm{~mm}$ in length and width (Figure 16)

NON-PLASTICS AND PASTE: grog

RIM AND LIP FORM: Direct rim and rounded lip

CORE COLOR: $\mathrm{G}$ (fired in a reducing environment and cooled in the open air)

INTERIOR SURFACE COLOR: very dark grayish-brown

EXTERIOR SURFACE COLOR: yellowish-brown; fire clouds on the rim, body, and base

WALL THICKNESS (IN MM): rim, $5.9 \mathrm{~mm}$

INTERIOR SURFACE TREATMENT: smoothed

EXTERIOR SURFACE TREATMENT: none

HEIGHT (IN CM): 18.1

ORIFICE DIAMETER (IN CM): 14.2

DIAMETER AT BOTTOM OF RIM OR NECK (IN CM): 14.2

BASE DIAMETER (IN CM) AND SHAPE OF BASE: $9.4 \mathrm{~cm}$, circular and flat

ESTIMATED VOLUME (IN LITERS): 1.5

\section{DECORATION (INCLUDING MOTIF AND ELEMENTS}

WHEN APPARENT): Although incised and punctated rather than engraved, the decorative elements on this vessel compare favorably to vars. F and var. M of Poynor Engraved (see Perttula 2011:Figure 6-65). The rim panel had five sets of incised triangles with curvilinear hatched corners and punctate-filled ovals (Figure 16). These sets are divided by sets of closelyspaced diagonal incised lines.

PIGMENT USE AND LOCATION ON VESSEL: none TYPE AND VARIETY (IF KNOWN): Poynor Incised

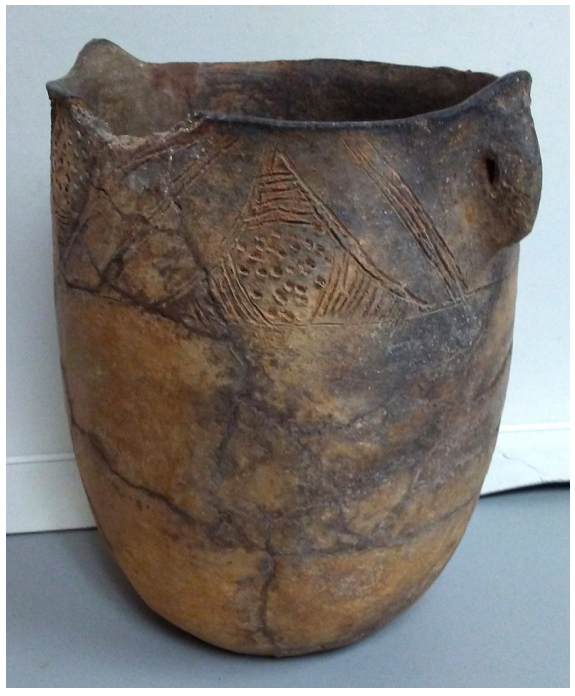

Figure 16. Poynor Incised jar (AN44-5) from the Jasper Tucker/Mrs. Joe Watkins Farm site. 
SITE NO.: 41AN44

FEATURE: Burial AO-1

VESSEL NO.: 41AN44-6

NON-PLASTICS: grog

VESSEL FORM: Bowl

RIM AND LIP FORM: direct rim and rounded lip

CORE COLOR: A (fired and cooled in an oxidizing environment)

INTERIOR SURFACE COLOR: light brown

EXTERIOR SURFACE COLOR: brown; fire clouds on the rim, body, and base

WALL THICKNESS: rim, $5.6 \mathrm{~mm}$

INTERIOR SURFACE TREATMENT: smoothed

EXTERIOR SURFACE TREATMENT: smoothed

HEIGHT: $10.5 ; 15.4 \mathrm{~cm}$ at the top of the effigy head

ORIFICE DIAMETER: 17.8

DIAMETER AT BOTTOM OF RIM OR NECK: N/A

BASE DIAMETER AND SHAPE: 11,2; circular and flat

ESTIMATED VOLUME: 0.75 liters

DECORATION: There are three horizontal engraved lines on the upper part of the bowl (Figure 17).

These lines dip down underneath the effigy head and the tab tail.

The effigy head (51 x $73 \times 11-18 \mathrm{~mm}$ in height, width, and thickness) resembles a duck head. It is facing inwards towards the tab tail, which is broken off. The effigy head has an engraved slit for its mouth and two circular holes for the nose; there are no eyes (see Figure 17). The tab tail is $66 \mathrm{~mm}$ in width.

PIGMENT: none

TYPE: Hood Engraved, var. Hood

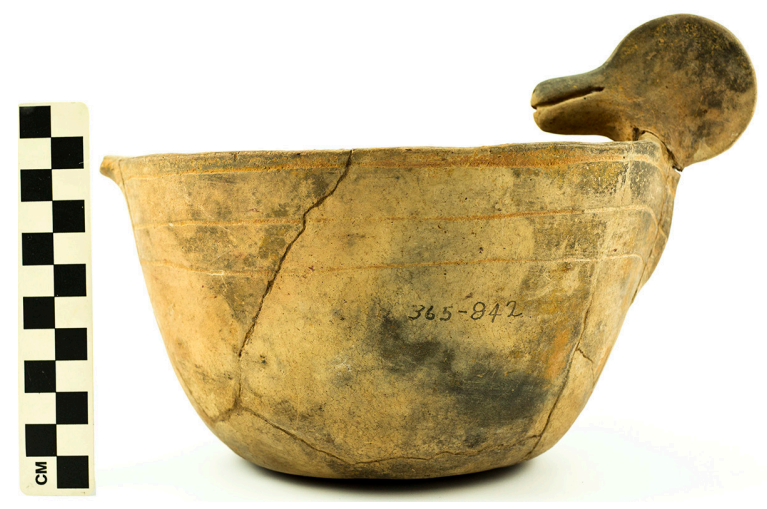

Figure 17. Hood Engraved, var. Hood effigy bowl (AN44-6) from the Jasper Tucker/Mrs. Joe Watkins Farm site. 
SITE NO.: 41AN44

FEATURE: Burial AO-1

VESSEL NO.: AN44-7

NON-PLASTICS: grog and hematite

VESSEL FORM: Bowl

RIM AND LIP FORM: direct rim and rounded lip

CORE COLOR: A (fired and cooled in an oxidizing environment)

INTERIOR SURFACE COLOR: light reddish-brown

EXTERIOR SURFACE COLOR: light reddish-brown

WALL THICKNESS: rim, $5.0 \mathrm{~mm}$

INTERIOR SURFACE TREATMENT: none

EXTERIOR SURFACE TREATMENT: smoothed

HEIGHT: $8.5 ; 12.0 \mathrm{~cm}$ atop the effigy head

ORIFICE DIAMETER: 14.6

DIAMETER AT BOTTOM OF RIM OR NECK: N/A

BASE DIAMETER AND SHAPE: 10.4; circular and flat

ESTIMATED VOLUME: 0.5 liters

DECORATION: There are three horizontal engraved lines around the rim (Figure 18). These lines dip below the effigy head and tab tail. There is a single horizontal engraved line across the tab tail.

The effigy head appears to be a duck head; it faces outward. It has an engraved slit for its mouth and two circular holes for its nose; there are no eyes (see Figure 18). It measures 51 x 73 x $11 \mathrm{~mm}$ in height, width, and thickness. The tab tail is 57 x $27 \times 14 \mathrm{~mm}$ in length, width, and thickness.

PIGMENT: none

TYPE: Hood Engraved, var. Hood

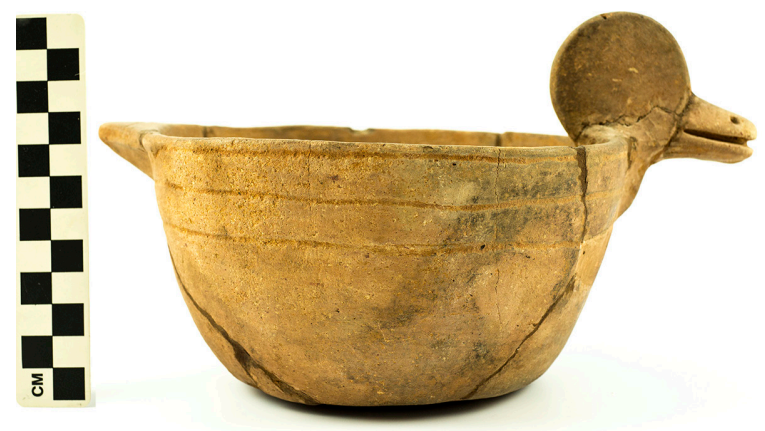

Figure 18. Hood Engraved, var. Hood effigy bowl (AN44-7) from the Jasper Tucker/Mrs. Joe Watkins Farm site. 
SITE NO.: 41AN44

FEATURE: Burial AO-1

VESSEL NO.: AN44-8

NON-PLASTICS: grog

VESSEL FORM: Bowl

RIM AND LIP FORM: direct rim and a flat lip

CORE COLOR: A (fired and cooled in an oxidizing environment)

INTERIOR SURFACE COLOR: light brown

EXTERIOR SURFACE COLOR: light brown to brown

WALL THICKNESS: rim, $5.4 \mathrm{~mm}$

INTERIOR SURFACE TREATMENT: smoothed

EXTERIOR SURFACE TREATMENT: smoothed to burnished

HEIGHT: $10.0 ; 14.6 \mathrm{~cm}$ in height atop effigy head

ORIFICE DIAMETER: 15.4

DIAMETER AT BOTTOM OF RIM OR NECK: N/A

BASE DIAMETER AND SHAPE: 10.2; circular and flat

ESTIMATED VOLUME: 0.62 liters

DECORATION: There are three horizontal engraved lines on the vessel, two below the rim and a third above the vessel base (Figure 19). The upper two engraved lines are continuous under the tab tail, but terminate at and below the effigy head attachment.

The effigy head resembles a duck head; it is facing inwards towards the tab tail. The duck head has an engraved slit for its mouth and two circular holes for its nose; there are no eyes (see Figure 19). The effigy head is $41 \times 62 \times 9 \mathrm{~mm}$ in height, width, and thickness. The tab tail is $39 \times 24 \times 9 \mathrm{~mm}$ in length, width, and thickness.

PIGMENT: none

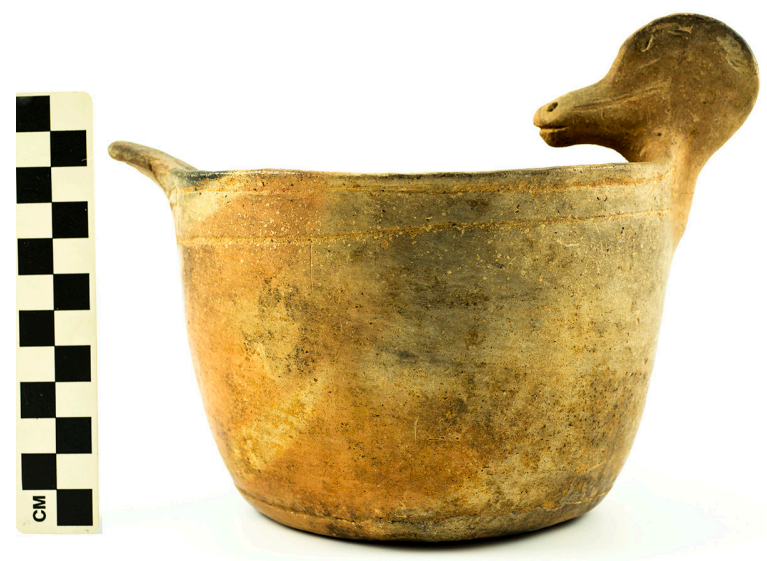

Figure 19. Hood Engraved, var. Hood effigy bowl (AN44-8) from the Jasper Tucker/Mrs. Joe Watkins Farm site.

TYPE: Hood Engraved, var. Hood 
SITE NO.: 41AN44

FEATURE: Burial AO-2

VESSEL NO.: AN44-14

NON-PLASTICS: grog

VESSEL FORM: Bowl

RIM AND LIP FORM: direct rim and rounded lip

CORE COLOR: A (fired and cooled in an oxidizing environment)

INTERIOR SURFACE COLOR: reddish-brown; fire clouds on the base

EXTERIOR SURFACE COLOR: reddish-brown; fire clouds on the rim and body

WALL THICKNESS: rim, $4.6 \mathrm{~mm}$

INTERIOR SURFACE TREATMENT: none

EXTERIOR SURFACE TREATMENT: none

HEIGHT: $3.5 ; 5.3 \mathrm{~cm}$ atop the effigy head

ORIFICE DIAMETER: 8.8

DIAMETER AT BOTTOM OF RIM OR NECK: N/A

BASE DIAMETER AND SHAPE: 2.9; circular and flat

ESTIMATED VOLUME: 0.13 liters

DECORATION: There are two to three irregularly executed horizontal engraved lines below the rim (Figure 20). These lines do not dip below the effigy head and tab tail attachments.

The effigy head $(22 \times 14 \times 10 \mathrm{~mm}$ in height, width, and thickness) appears to be the head, mouth, and ears of an unknown animal; it is not a bird head. The head faces inwards towards the tab tail (see Figure 20). The tab tail is partly broken off the vessel; it is $21 \mathrm{~mm}$ in width and $6.0 \mathrm{~mm}$ in thickness.

PIGMENT: red pigment in engraved lines

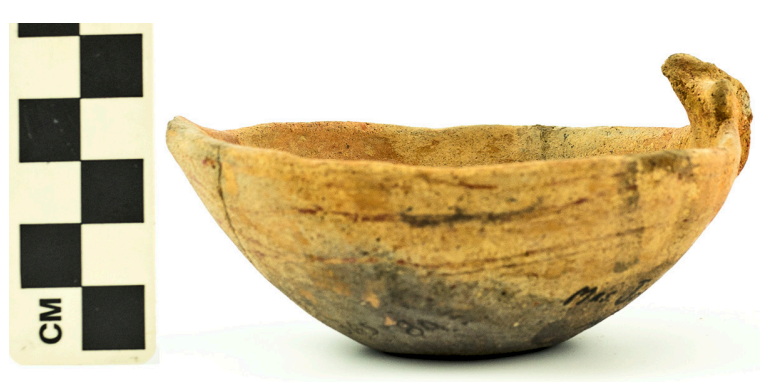

TYPE: Hood Engraved, var. Hood

Figure 20. Hood Engraved, var. Hood effigy bowl (AN44-14) from the Jasper Tucker/Mrs. Joe Watkins Farm site. 
SITE NAME OR SITE NUMBER: 41AN44

VESSEL NO.: AN44-15, Burial AO-2

VESSEL FORM: Bottle

NON-PLASTICS AND PASTE: grog

RIM AND LIP FORM: Direct rim with flat and scalloped Redwine mode lip (Figure 21) (see Walters 2010)

CORE COLOR: $\mathrm{G}$ (fired in a reducing environment and cooled in the open air)

INTERIOR SURFACE COLOR: dark gray

EXTERIOR SURFACE COLOR: reddish-brown; fire clouds on the rim, body, and base

WALL THICKNESS (IN MM): rim, $4.9 \mathrm{~mm}$

INTERIOR SURFACE TREATMENT: none

EXTERIOR SURFACE TREATMENT: smoothed

HEIGHT (IN CM): 15.7

ORIFICE DIAMETER (IN CM): 6.0

DIAMETER AT BOTTOM OF RIM OR NECK (IN CM): $7.3 \mathrm{~cm}$; maximum body diameter: $10.8 \mathrm{~cm}$

BASE DIAMETER (IN CM) AND SHAPE OF BASE: $7.2 \mathrm{~cm}$, circular and flat

ESTIMATED VOLUME (IN LITERS): 0.5

DECORATION (INCLUDING MOTIF AND ELEMENTS WHEN APPARENT): The bottle neck has three rectangular engraved panels with closely-spaced vertical engraved lines and curvilinear hatched corners and a central circle element filled with excised punctations (Figure 21). Between the three panels are closelyspaced sets of two vertical engraved lines.

PIGMENT USE AND LOCATION ON VESSEL: none

TYPE AND VARIETY (IF KNOWN): Poynor Engraved, var. Blackburn (see Perttula 2011:Figure 6-64b')

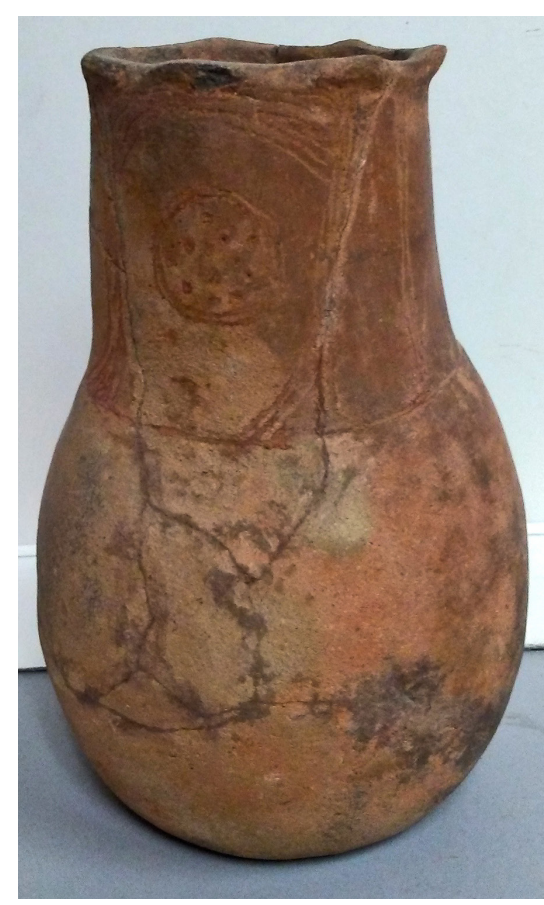

Figure 21. Poynor Engraved, var. Blackburn bottle (AN44-15) from the Jasper Tucker/Mrs. Joe Watkins Farm site. 
SITE NAME OR SITE NUMBER: Jasper Tucker/Mrs. Joe Watkins

VESSEL NO.: AN44-17

VESSEL FORM: Bowl

NON-PLASTICS AND PASTE: grog and hematite

RIM AND LIP FORM: Direct rim and rounded lip

CORE COLOR: $\mathrm{F}$ (fired in a reducing environment and cooled in the open air)

INTERIOR SURFACE COLOR: reddish-brown; fire clouds on the rim, body, and base

EXTERIOR SURFACE COLOR: reddish-brown; fire clouds on the rim, body, and base

WALL THICKNESS (IN MM): rim, $6.1 \mathrm{~mm}$

INTERIOR SURFACE TREATMENT: smoothed

EXTERIOR SURFACE TREATMENT: burnished

HEIGHT (IN CM): 6.2

ORIFICE DIAMETER (IN CM): 10.5

DIAMETER AT BOTTOM OF RIM OR NECK (IN CM): N/A

BASE DIAMETER (IN CM) AND SHAPE OF BASE: $7.0 \mathrm{~cm}$, circular and flat

ESTIMATED VOLUME (IN LITERS): 0.3

DECORATION (INCLUDING MOTIF AND

ELEMENTS WHEN APPARENT): Plain (Figure 22)

PIGMENT USE AND LOCATION ON VESSEL: none

TYPE AND VARIETY (IF KNOWN): Unidentified plain ware

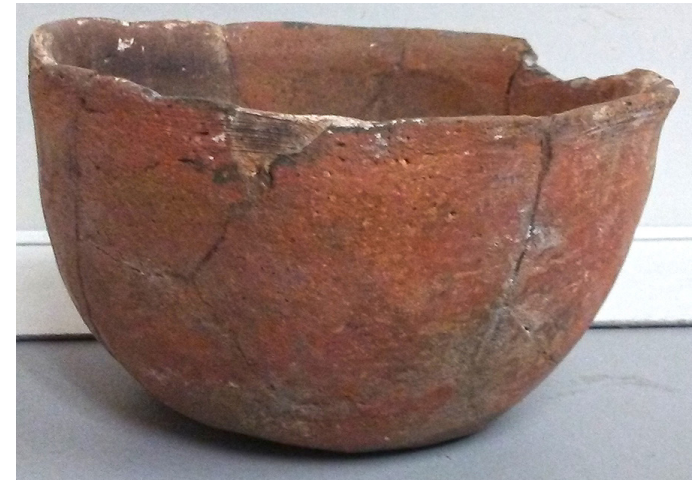

Figure 22. Plain bowl (AN44-17) from the Jasper Tucker/Mrs. Joe Watkins Farm site. 
SITE NAME OR SITE NUMBER: Jasper Tucker/Mrs. Joe Watkins Farm

VESSEL NO.: AN44-18

VESSEL FORM: Jar

NON-PLASTICS AND PASTE: grog

RIM AND LIP FORM: Everted rim and rounded lip

CORE COLOR: $\mathrm{G}$ (fired in a reducing environment and cooled in the open air)

INTERIOR SURFACE COLOR: dark grayish-brown

EXTERIOR SURFACE COLOR: brown; fire clouds on the body and base

WALL THICKNESS (IN MM): rim, $4.7 \mathrm{~mm}$; body, $4.5 \mathrm{~mm}$

INTERIOR SURFACE TREATMENT: smoothed

EXTERIOR SURFACE TREATMENT: smoothed on the body

HEIGHT (IN CM): 12.5

ORIFICE DIAMETER (IN CM): 8.3

DIAMETER AT BOTTOM OF RIM OR NECK (IN CM): 8.1

BASE DIAMETER (IN CM) AND SHAPE OF BASE: $5.7 \mathrm{~cm}$, circular and flat

ESTIMATED VOLUME (IN LITERS): 0.6

DECORATION (INCLUDING MOTIF AND ELEMENTS WHEN APPARENT): The rim panel has sets of opposed diagonal incised lines around the vessel (Figure 23).

PIGMENT USE AND LOCATION ON VESSEL:

TYPE AND VARIETY (IF KNOWN): Maydelle Incised

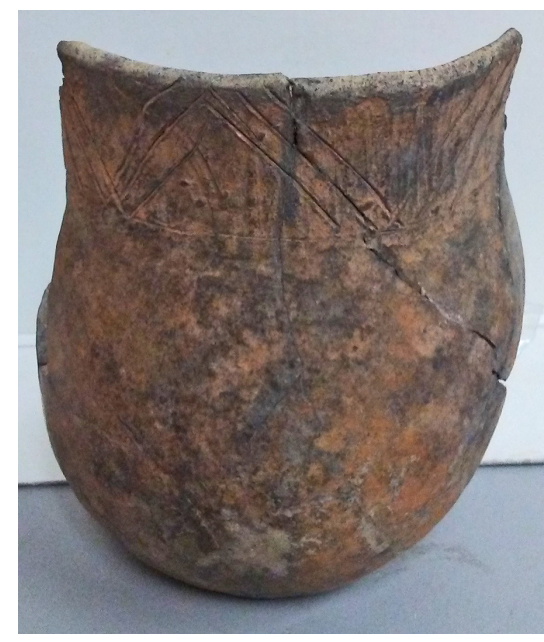

Figure 23. Maydelle Incised jar (AN44-18) from the Jasper Tucker/ Mrs. Joe Watkins Farm site. 
SITE NAME OR SITE NUMBER: Jasper Tucker/Mrs. Joe Watkins Farm

VESSEL NO.: AN44-19

VESSEL FORM: Jar

NON-PLASTICS AND PASTE: grog and hematite

RIM AND LIP FORM: Everted rim and rounded lip

CORE COLOR: $\mathrm{F}$ (fired in a reducing environment and cooled in the open air)

INTERIOR SURFACE COLOR: light brown

EXTERIOR SURFACE COLOR: light brown; fire clouds on the base

WALL THICKNESS (IN MM): rim, $4.4 \mathrm{~mm}$; body, $6.3 \mathrm{~mm}$

INTERIOR SURFACE TREATMENT: smoothed

EXTERIOR SURFACE TREATMENT: smoothed

HEIGHT (IN CM): 11.8

ORIFICE DIAMETER (IN CM): 13.3

DIAMETER AT BOTTOM OF RIM OR NECK (IN CM): 12.7

BASE DIAMETER (IN CM) AND SHAPE OF BASE: $9.6 \mathrm{~cm}$, circular and flat

ESTIMATED VOLUME (IN LITERS): 0.9

DECORATION (INCLUDING MOTIF AND

ELEMENTS WHEN APPARENT): The rim has panels defined by sets of closely-spaced vertical engraved lines with curvilinear hatched triangle elements (Figure 24ab). The central part of the panel has one or more diagonal engraved lines with either upper or lower hatched triangle elements.

PIGMENT USE AND LOCATION ON VESSEL: none

TYPE AND VARIETY (IF KNOWN): Poynor Engraved, var. Blackburn
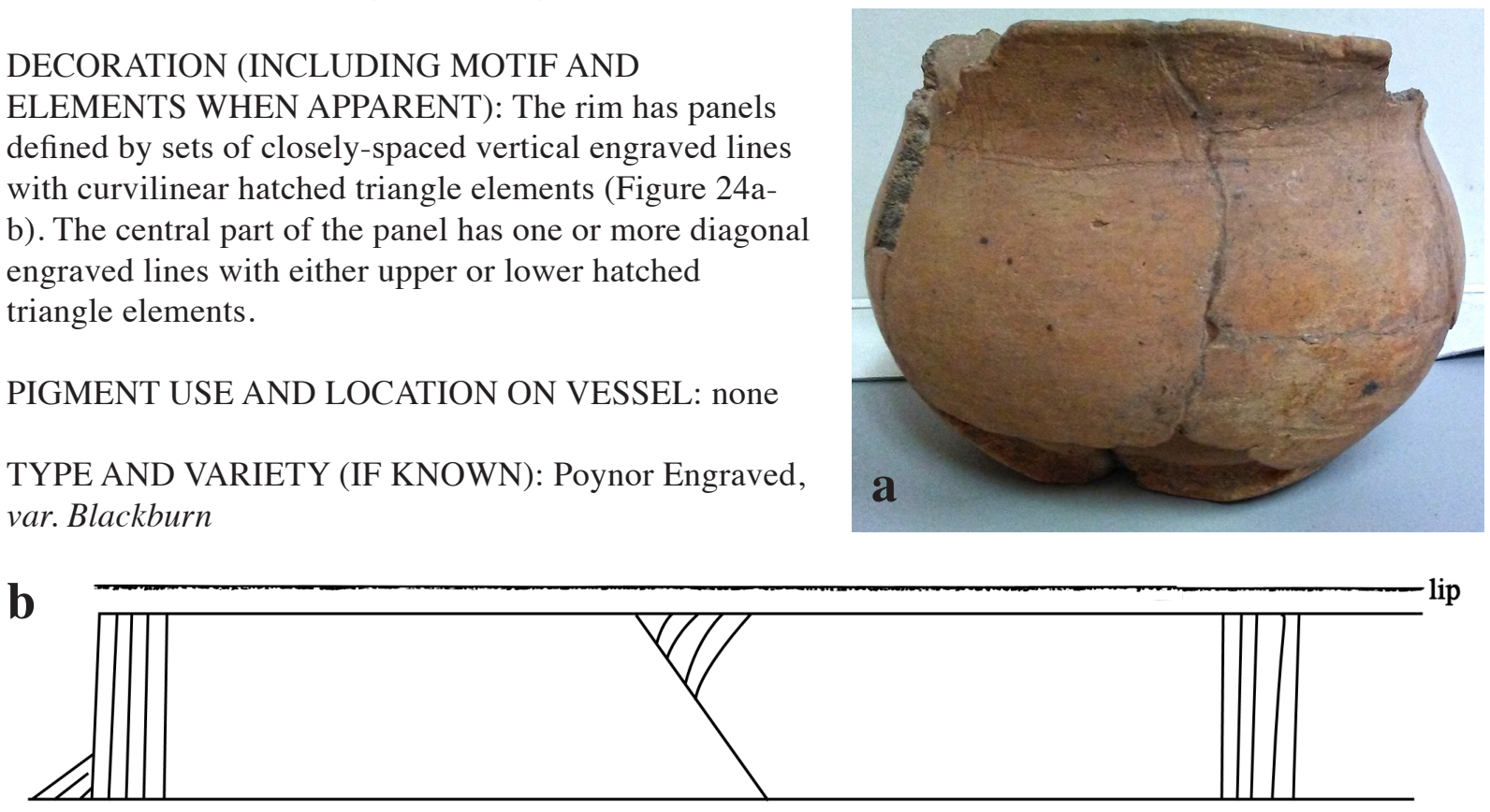

Figure 24. Poynor Engraved, var. Blackburn jar (AN44-19) from the Jasper Tucker/Mrs. Joe Watkins Farm site: a, photo; b, decorative elements. 


\section{W. T. Todd Site (41AN52)}

The W. T. Todd vessel was collected by persons unknown in 1927, who collected several vessels at the site following flooding along Brushy Creek, an eastward-flowing tributary to the Neches River. UT purchased one vessel in 1931.

SITE NAME OR SITE NUMBER: W. T. Todd

VESSEL NO.: AN52-1

VESSEL FORM: Bottle with an elongated body and short neck (Figure 25; see also Suhm and Jelks 1962:Figure 42e)

NON-PLASTICS AND PASTE: grog and hematite

RIM AND LIP FORM: N/A

CORE COLOR: G (fired in a reducing environment and cooled in the open air)

INTERIOR SURFACE COLOR: dark grayish-brown

EXTERIOR SURFACE COLOR: light reddish-brown; fire clouds on the body and base

WALL THICKNESS (IN MM): rim, $6.3 \mathrm{~mm}$

INTERIOR SURFACE TREATMENT: none

EXTERIOR SURFACE TREATMENT: none

HEIGHT (IN CM): 18.4+

ORIFICE DIAMETER (IN CM): N/A

DIAMETER AT BOTTOM OF RIM OR NECK (IN CM): $4.3 \mathrm{~cm}$; maximum body diameter: $13.2 \mathrm{~cm}$

BASE DIAMETER (IN CM) AND SHAPE OF BASE: $7.4 \mathrm{~cm}$, circular and flat

ESTIMATED VOLUME (IN LITERS): 0.5+

DECORATION (INCLUDING MOTIF AND ELEMENTS WHEN APPARENT): The bottom of the vessel neck has at least three horizontal engraved lines, while the vessel body has three sets of narrow vertical engraved panels filled with diagonal engraved lines (Figure 25). These panels end within $3.2 \mathrm{~cm}$ of the vessel base.

PIGMENT USE AND LOCATION ON VESSEL: none

TYPE AND VARIETY (IF KNOWN): Hume Engraved, var. Hume

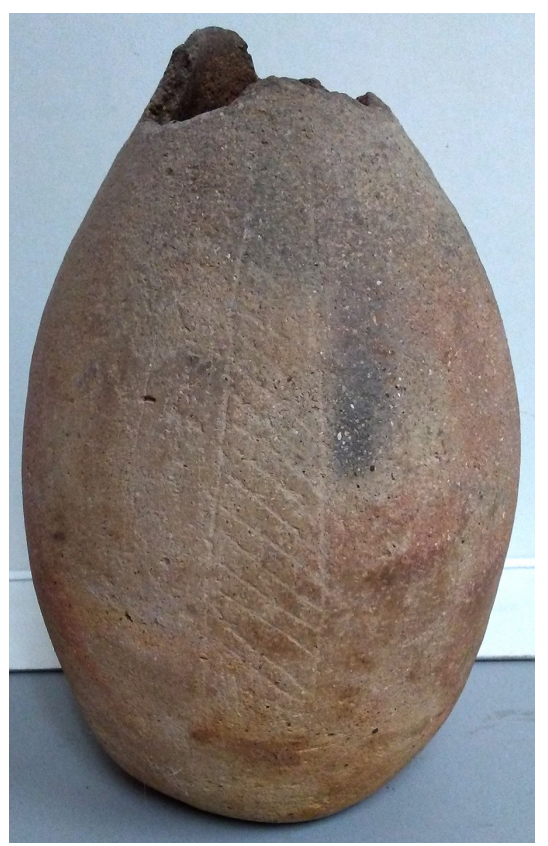

Figure 25. Hume Engraved, var. Hume bottle (AN52-1) from the W. T. Todd site. 


\section{N. B. Ruggles Site (41CE40)}

The N. B. Ruggles ceramic vessels were from a burial disturbed by plowing, and the landowner recovered two vessels and a celt from the site. The site is reported by A. T. Jackson (Fieldbook \#2 for 1931, on file at TARL) to be ca. 3 miles north of Jacksonville, Texas, in the upper Neches River basin. The landowner subsequently sold these funerary artifacts to J. E. Haley in 1931, who donated them to UT in June 1931. A Ray Odom found four other ceramic vessels and a ceramic pipe from a road cut bank at the site, but these are not in the TARL collections.

SITE NAME OR SITE NUMBER: N. B. Ruggles

VESSEL NO.: 33

VESSEL FORM: Bottle with a carinated body (Figure 26a)

NON-PLASTICS AND PASTE: grog and hematite

RIM AND LIP FORM: Direct rim and rounded lip

CORE COLOR: $\mathrm{G}$ (fired in a reducing environment and cooled in the open air)

INTERIOR SURFACE COLOR: gray

EXTERIOR SURFACE COLOR: reddish-brown; fire clouds on the base

WALL THICKNESS (IN MM): rim, $5.7 \mathrm{~mm}$

INTERIOR SURFACE TREATMENT: none

EXTERIOR SURFACE TREATMENT: none

HEIGHT (IN CM): 23.4

ORIFICE DIAMETER (IN CM): 4.3

DIAMETER AT BOTTOM OF RIM OR NECK (IN CM): $5.8 \mathrm{~cm}$; maximum body diameter: $18.4 \mathrm{~cm}$

BASE DIAMETER (IN CM) AND SHAPE OF BASE: $10.2 \mathrm{~cm}$, circular and flat

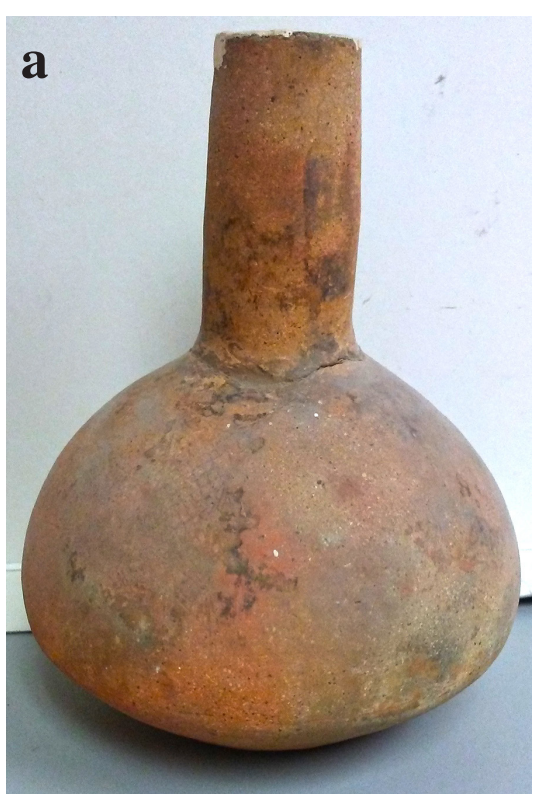

ESTIMATED VOLUME (IN LITERS): 1.0

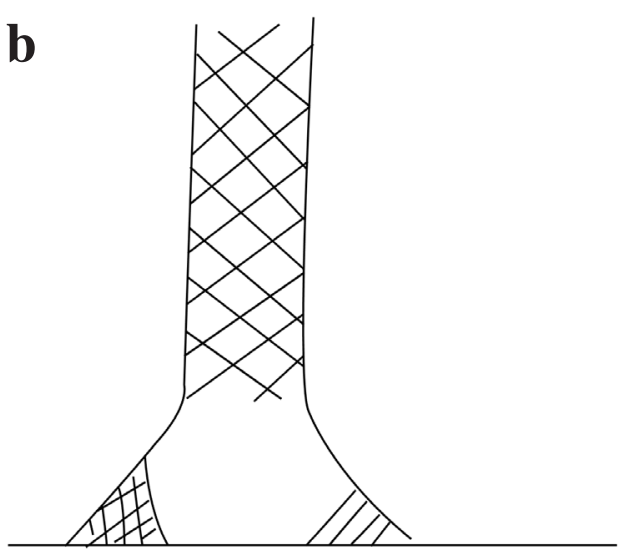

Figure 26. Hume Engraved, var. Hume bottle (No. 33) from the N. B. Ruggles site: $\mathrm{a}$, photo; $\mathrm{b}$, decorative elements.

DECORATION (INCLUDING MOTIF AND ELEMENTS WHEN APPARENT): The vessel body has four equally-spaced sets of narrow vertical engraved panels filled with cross-hatched lines (Figure 26b). Near the vessel base, the panels take on a triangular shape, and the corners of these areas have diagonal hatched or cross-hatched triangular elements.

PIGMENT USE AND LOCATION ON VESSEL: none

TYPE AND VARIETY (IF KNOWN): Hume Engraved, var. Hume 
SITE NAME OR SITE NUMBER: N. B. Ruggles

VESSEL NO.: 34

VESSEL FORM: Jar with two opposed lug handles (27 x $14 \mathrm{~mm}$ in length and width) (Figure 27)

NON-PLASTICS AND PASTE: hematite

RIM AND LIP FORM: Direct rim and rounded lip

CORE COLOR: $\mathrm{F}$ (fired in a reducing environment and cooled in the open air)

INTERIOR SURFACE COLOR: reddish-brown; fire clouds on the rim and body

EXTERIOR SURFACE COLOR: reddish-brown; fire clouds on the rim, body, and base; organic residue on the rim and body

WALL THICKNESS (IN MM): rim, $8.1 \mathrm{~mm}$

INTERIOR SURFACE TREATMENT: smoothed

EXTERIOR SURFACE TREATMENT: none

HEIGHT (IN CM): 22.6

ORIFICE DIAMETER (IN CM): 17.0

DIAMETER AT BOTTOM OF RIM OR NECK (IN CM): 16.8

BASE DIAMETER (IN CM) AND SHAPE OF BASE: $10.5 \mathrm{~cm}$, circular and flat

ESTIMATED VOLUME (IN LITERS): 3.5

\section{DECORATION (INCLUDING MOTIF AND ELEMENTS}

WHEN APPARENT): The vessel rim has six horizontal rows of tool punctations, and the vessel body has vertical brushing marks that extend to within $3.7 \mathrm{~cm}$ of the vessel base (Figure 27).

PIGMENT USE AND LOCATION ON VESSEL: none

TYPE AND VARIETY (IF KNOWN): Bullard Brushed

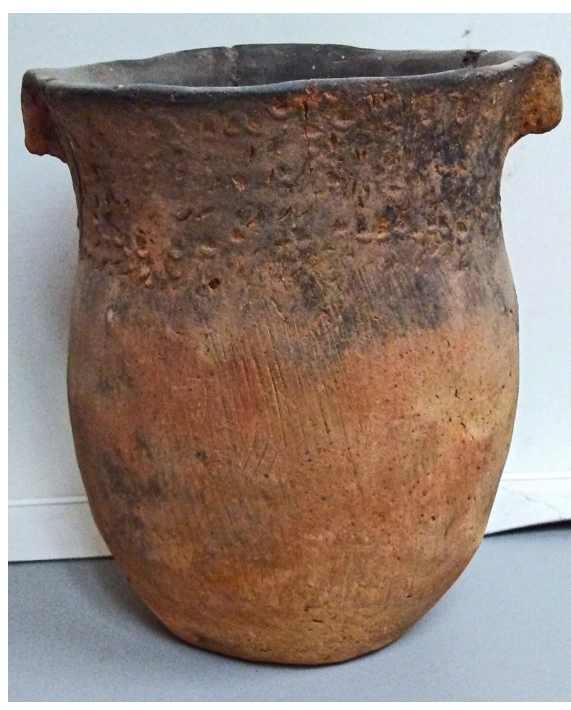

Figure 27. Bullard Brushed jar (No. 34) from the N. B. Ruggles site. 


\section{General, Cherokee County}

This vessel was found near Rusk, Texas and was donated to UT in August 1926.

SITE NAME OR SITE NUMBER: General, Cherokee County

VESSEL NO.: Gen-1

VESSEL FORM: Globular carinated bowl (Figure 28)

NON-PLASTICS AND PASTE: grog and hematite

RIM AND LIP FORM: Direct rim and rounded lip

CORE COLOR: $\mathrm{F}$ (fired in a reducing environment and cooled in the open air)

INTERIOR SURFACE COLOR: light yellowish-brown; fire clouds on the rim

EXTERIOR SURFACE COLOR: light yellowish-brown; fire clouds on the rim, body, and base

WALL THICKNESS (IN MM): rim, $4.6 \mathrm{~mm}$

INTERIOR SURFACE TREATMENT: smoothed

EXTERIOR SURFACE TREATMENT: smoothed

HEIGHT (IN CM): 8.9

ORIFICE DIAMETER (IN CM): 10.8

DIAMETER AT BOTTOM OF RIM OR NECK (IN CM): 10.8

BASE DIAMETER (IN CM) AND SHAPE OF BASE:

$7.3 \mathrm{~cm}$, circular and flat

ESTIMATED VOLUME (IN LITERS): 0.6

DECORATION (INCLUDING MOTIF AND

ELEMENTS WHEN APPARENT): The rim panel has nine sets of negative ovals defined by engraved bracket elements filled with curvilinear engraved lines and upper and lower pendant triangles (Figure 28).

PIGMENT USE AND LOCATION ON VESSEL: none

TYPE AND VARIETY (IF KNOWN): Poynor Engraved, var. Cook

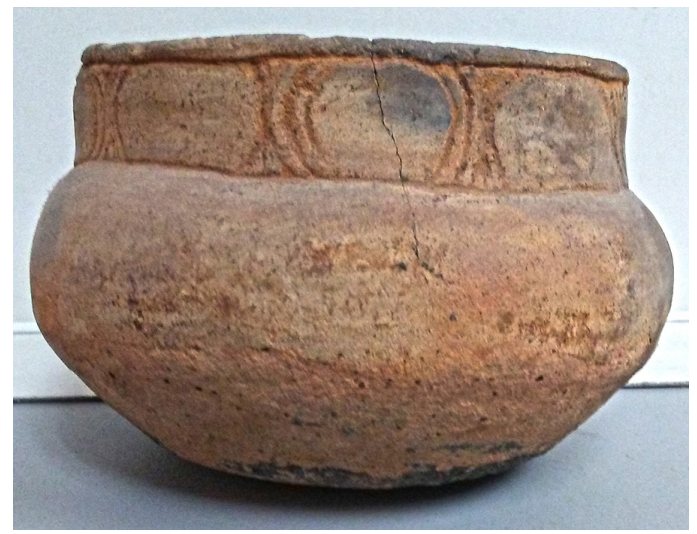

Figure 28. Poynor Engraved, var. Cook carinated bowl (Gen-1), Cherokee County, Texas. 


\section{Summary and Conclusions}

Twenty-eight ancestral Caddo ceramic vessels in the Texas Archeological Research Laboratory vessel collections from seven sites in Anderson and Cherokee counties (and one vessel from a general collection for Cherokee County) in the upper Neches River basin of East Texas have been documented in this article. The vessels are from burial features that are affiliated with Caddo peoples of the Late Caddo period Frankston phase, in sites dating generally from ca. A.D. 1400-1680. The range of identified types and varieties in these collections suggest that they are from burial features that date primarily from ca. A.D. 1400-1560 (see Perttula 2011:Table 6-37); the absence of Poynor Engraved, var. Freeman or any Patton Engraved vessels in these assemblages is notable in this respect.

The 28 vessels, grog- and grog-hematite-tempered, are of five different vessel forms, and from small to medium-sized vessels in volume and height. This includes jars $(n=7,25$ percent $)$, carinated bowls $(n=6,21.4$ percent), effigy bowls $(n=6,21.4$ percent), bottles $(n=5,17.9$ percent $)$, and bowls $(n=4,14.3$ percent). Of these vessels, two are plain ware (7.1 percent), another six (21.4 percent) are from utility ware, and the remaining 71.4 percent are from engraved fine wares.

The defined utility ware types in these vessel assemblages include Maydelle Incised, Killough Pinched, and Bullard Brushed, as well as one Poynor Incised jar; this vessel has a wet paste decoration of a motif otherwise found on certain Poynor Engraved vessels in the upper Neches River basin. The fine wares are from Poynor Engraved $(n=9)$, Hood Engraved $(n=6)$, cf. Hood Engraved $(n=2)$, and Hume Engraved ( $n=2)$; one fine ware vessel in these collections could not be identified to a defined type. The Poynor Engraved vessels are represented by var. Blackburn $(\mathrm{n}=2), \operatorname{var}$. Cook $(\mathrm{n}=3)$, var. Hood $(\mathrm{n}=1)$, and var. $N(\mathrm{n}=1)$, while all the Hood Engraved vessels are var. Hood. Lastly, both Hume Engraved bottles in the collections are var. Hume vessels.

\section{Acknowledgments}

Thanks to Marybeth Tomka for access to the vessel collections at the Texas Archeological Research Laboratory at The University of Texas at Austin. Lance Trask prepared several figures in this article.

\section{References Cited}

Jackson, A. T.

1931 Ed. W. Ellis Farm, October 13 to October 15, 1931. MS on file, Texas Archeological Research Laboratory, The University of Texas at Austin.

Perttula, T. K.

2011 The Ceramic Artifacts from the Lang Pasture Site (41AN38) and the Place of the Site within an Upper Neches River Basin Caddo Ceramic Tradition. In Archeological Investigations at the Lang Pasture Site (41AN38) in the Upper Neches River Basin of East Texas, assembled and edited by T. K. Perttula, D. B. Kelley, and R. A. Ricklis, pp. 145-320. Archeological Studies Program Report No. 129, Texas Department of Transportation, Environmental Affairs Division, Austin.

2018 A Study of Ancestral Caddo Ceramic Vessels from Titus Phase Sites in Camp, Franklin, Harrison, Marion, Morris, Titus, and Upshur Counties in East Texas. Special Publication No. 52. Friends of Northeast Texas Archaeology, Austin and Pittsburg.

Perttula, T. K. and R. Z. Selden, Jr.

2015 Effigy Vessel Documentation, Caddo Collections at the Texas Archeological Research Laboratory at The University of Texas at Austin. Special Publication No. 40. Friends of Northeast Texas Archaeology, Austin and Pittsburg. 
Suhm, D. A. and E. B. Jelks (editors)

1962 Handbook of Texas Archeology: Type Descriptions. Special Publication No. 1, Texas Archeological Society, and Bulletin No. 4, Texas Memorial Museum, Austin.

Walters, M., with contributions by T. Middlebrook and T. K. Perttula

2010 Redwine or Pie-Crust Mode Forms in East Texas Caddo Ceramics and comparisons with SprocketRims of Southwest Arkansas. Caddo Archeology Journal 20:77-128.

Woolsey, A. M.

1935a Notes on Field Work Rube Beard Farm, 2 1/2 Miles South of Frankston, Anderson County, October 12, 1935. MS on file, Texas Archeological Research Laboratory, The University of Texas at Austin.

1935b Notes on Field Work, Jasper Tucker Farm, Mrs. Joe Watkins Owner, 9 Miles Southwest of Frankston, Anderson County, November 20 to November 22, 1935. MS on file, Texas Archeological Research Laboratory, The University of Texas at Austin. 